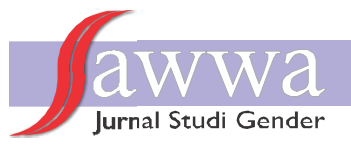

\title{
Kota Layak Anak Berbasis Collaborative Governance
}

\author{
Noverman Duadji, \\ Novita Tresiana \\ Puslitbang Wanita, Anak dan \\ Pembangunan LPPM Universitas \\ Lampung (Unila), Bandar Lampung, \\ Indonesia \\ email: novermanduadji@unila.ac.id
}

\begin{abstract}
This paper describes the development of collaborative governance-based city/district, so it is hoped that children's policies and programs with holistic, integrative and sustainable character will be developed. This paper is the result of research aimed at: 1) mapping the problem and potential of children as the central issue that can be developed as a development issue; 2 ) develop an ideal city/district ideal child model. The research method used qualitative descriptive. Research location in Lampung Province. The results of the study describe children problems including child abuse, disability children, children faced with the law and abandoned babies due to policies and programs that are not partial to children, policies are partial, segmentative and sectorally arranged, no cooperation/partners with other institutions. The existence of local policy potential in the form of various policies and local regulations, the number of social institutions of children into social capital is strong physically and socially in building the collaborative model/partnership.
\end{abstract}

Keywords: child; collaboration; sustainable program

Abstrak: Tulisan ini menjelaskan pembangunan kota/kabupaten layak anak yang berbasis kolaborasi (collaborative governance), sehingga diharapkan akan lahir kebijakan dan program anak yang berkarakter holistik, integratif, dan berkelanjutan. Tulisan ini merupakan hasil penelitian yang ditujukan untuk: 1) pemetaan masalah dan potensi anak sebagai isu sentral yang dapat dikembangkan sebagai isu pembangunan; 2) mengembangkan model kota/kabupaten layak anak yang ideal. Metode penelitian menggunakan kualitatif deskriptif. Lokasi penelitian di Provinsi Lampung. Hasil penelitian mendeskripsikan terjadi masalah anak meliputi kekerasan anak, anak disabilitas (ADS), anak berhadapan dengan hukum (ABH) dan bayi terlantar disebabkan kebijakan dan program yang belum berpihak pada anak, kebijakan tersusun secara parsial, segmentatif, dan sektoral, tidak ada kerjasama dengan kelembagaan lainnya. Adanya potensi kebijakan daerah berupa berbagai kebijakan dan peraturan daerah, banyaknya lembaga kemasyarakatan anak menjadi modal sosial yang kuat secara fisik dan sosial dalam membangun model kolaboratif/ kemitraan.

Kata Kunci: anak; kolaborasi; program berkelanjutan 


\section{A. Pendahuluan}

Pembangunan untuk mewujudkan hak-hak anak berupa perlindungan anak dan tumbuh kembang anak di Indonesia telah memiliki landasan konstitusional dan juga menjadi komitmen internasional. Persoalan khusus anak karena berbagai perlakuan buruk yang menghambat tumbuh kembang anak secara optimal telah menghadirkan konvensi hak anak, yang diadopsi oleh PBB pada tahun 1989. Ada 4 prinsip dasar hak anak yang terkandung di dalam Konvensi Hak Anak sebagaimana dilansir Kementerian Pemberdayaan Perempuan dan Perlindungan Anak,, yaitu: 1) prinsip non-diskriminasi,tidak ada pembenaran terhadap diskriminasi atas alasan apapun; 2) prinsip kepentingan terbaik anak; 3) hak atas untuk hidup, kelangsungan hidup, dan perkembangan; serta 4) penghargaan terhadap pendapat anak. Sedangkan Islam telah memberikan perhatian yang sangat besar terhadap perlindungan anakanak. Perlindungan dalam Islam meliputi fisik, psikis, intelektual, moral, ekonomi, dan lainnya. Hal ini dijabarkan dalam bentuk mmemenuhi semua hak-haknya, menjamin kebutuhan sandang dan pangannya, menjaga nama baik dan martabatnya, menjaga kesehatannya, memilihkan teman bergaul yang baik, menghindarkan dari kekerasan, dan lain-lain. ${ }^{2}$

Komitmen di tingkat nasional juga telah diperjuangkan melalui berbagai undang-undang untuk melindungi anak, antara lain UU tentang Perlindungan Anak, yakni UU No. 23 Tahun 2002 dan UU perubahannya yakni UU No. 35 Tahun 2014, maupun UU tentang Sistem Peradilan Pidana Anak, yaitu UU No. 11 Tahun 2012. Meski demikian, berbagai persoalan kekerasan dan hambatan tumbuh kembang anak tidak kunjung berakhir, sebaliknya muncul dalam bentuk yang sangat bervariatif dan kompleks. ${ }^{3}$

Dalam konteks pembangunan lokal, Provinsi Lampung telah menetapkan Pengarusutamaan Hak Anak (PUHA) sebagai sebuah strategi perlindungan anak dengan mengintegrasikan hak anak ke dalam setiap kegiatan pembangunan,

${ }^{1}$ Noverman Duadji, dan Novita Tresiana, Kota Layak Anak yang Berkelanjutan (Lampung: Aura Press, 2017).

2Muhammad Zaki, "Perlindungan Anak dalam Perspektif Islam”, Jurnal Asas 6 no. 2 (2014).

${ }^{3}$ Duadji, dan Tresiana, Kota Layak Anakyang Berkelanjutan. 
mulai sejak penyusunan perencanaan, penganggaran, pelaksanaan, pemantauan, dan evaluasi dari berbagai peraturan perundangan-undangan, kebijakan, program, dan kegiatan dengan menerapkan prinsip kepentingan terbaik bagi anak. Untuk mengimplementasikannya, maka kebijakan PUHA salah satunya ditransformasikan melalui kebijakan pembangunan Kabupaten/Kota Layak Anak (KLA) yang merupakan upaya pemerintahan setiap kabupaten/kota di Provinsi Lampung untuk mempercepat implementasi Konvensi Hak Anak (KHA) dari kerangka hukum ke dalam definisi, strategi, dan intervensi pembangunan seperti kebijakan, institusi, dan program yang layak anak.

Meskipun berbagai pembangunan kota/kabupaten layak anak telah digulirkan di yang ditujukan untuk memperkecil atau menghapus persoalan anak, namun ternyata isu anak belumlah mampu menjadi pusat perhatian pembangunan di kabupaten/kota. Pelaksanaan pembangunan di daerah selama ini lebih menekankan pada pembangunan ekonomi, politik dan infrastruktur, tanpa mempertimbangkan unsur kepentingan terbaik anak dalam pengambilan keputusan. Banyak kebijakan pembangunan yang belum berpihak pada anak, sehingga bias dalam implementasinya dan birokrasi pemerintah nampaknya juga belum responsif anak karena belum adanya kesadaran dari pembuat kebijakan ataupun pimpinan birokrasi terhadap pentingnya isu anak dalam kebijakan-kebijakan yang disusun. ${ }^{4}$

Guna mengantisipasi kegagalan potensi-potensi yang dapat mengganggu proses pembangunan kota layak anak, maka pemerintah perlu merubah pola memerintah (governance) dengan melakukan penguatan melalui kerjasama dan pengembangan model proses komunikasi dan tindakan bersama dengan kelembagaan lain. Fokus tata perubahan pengelolaan dilakukan pada proses perencanaan dan merumuskan kebijakan yang semula dilakukan sendiri oleh pemerintah, dirubah dengan melibatkan multi-stakeholders lainnya. Model tata kelola pemerintahan yang melibatkan multi-stakeholders untuk mengambil keputusan publik di sebut collaborative governance.

Istilah collaborative governance dikemukakan oleh Ansell dan Gash, merujuk pada adanya komunikasi dan tindakan bersama dengan para pemangku

${ }^{4}$ Duadji, Noverman dkk, "Model Percepatan Kota Layak Anak", (Laporan penelitian tidak dipublikasikan, Universitas Lampung, 2017). 
kepentingan (multi-stakeholders), dimana para pemangku kepentingan duduk bersama untuk mengambil suatu keputusan publik yang merupakan hasil konsensus melalui suatu proses dialog warga secara tatap muka. ${ }^{5}$ Proses dialog tatap muka bukan merupakan bagian dari tahapan, bukan merupakan salah satu tahapan proses, tetapi mewarnai seluruh tahapan proses kolaboratif. Senada dengan di atas Umrina, dkk..$^{6}$ memperkuat peran dialog warga dalam pengambilan keputusan, sedangkan Tresiana dan Duadji merekomendasikan model multistakeholders governance body untuk menghasilan keputusan yang baik. ${ }^{7}$

Dikembangkannya model collaborative governance yang berkaitan dengan membangun kota layak anak, berkaitan dengan paradigma pembangunan anak selama ini yang sangat parsial, segmentatif, sektoral, belum berintegrasi dengan kelembagaan masyarakat lainnya, kurang mengikutsertakan atau melibatkan potensi yang dimiliki masyarakat. Dalam model collaborative governance, konsep merumuskan kebijakan pembangunan kota layak anak dilakukan dengan mendayagunakan semua potensi yang ada di masyarakat untuk mengembangkan/menumbuhkan pemecahan-pemecahan masalah anak secara kreatif, bersifat holistik, integratif, dan berkelanjutan. Model pembangunan anak ini mencoba untuk mencari keserasian antara pendekatan pengelolaan dari atas dan dari bawah berdasarkan keterlibatan semua pihak. Al-Qur'an telah memberikan tuntunan bekerjasama, tolong menolong dalam melakukan suatu pekerjaan yang baik atau sesuai syariat Islam:

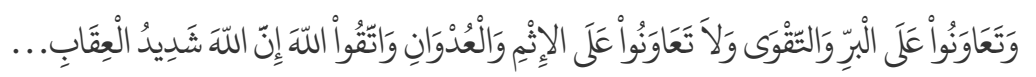

“... dan tolong-menolonglah kamu dalam (mengerjakan) kebajikan dan takwa, dan jangan tolong-menolong dalam berbuat dosa dan pelanggaran, dan bertakwalah kamu kepada Allah, sesungguhnya Allah amat berat siksa-Nya."

Collaborative adalah komponen utama demokrasi Islam, sebagai unsur penting yang menjamin kecemerlangan dan keberhasilan program, yang dalam

${ }^{5}$ C. Ansell dan A. Gash, "Collaborative Governance in Theory and Practice", Journal of Publik Administration Research and Theory 18(2007): 543-571.

${ }^{6}$ Anila Umriana, Moh. Fauzi, dan Hasyim Hasanah, "Hak Asasi Perempuan dan Kesetaraan Gender Melalui Dialog Warga”, Jurnal Sawwa 12, no. 1 (2016): 41-59.

${ }^{7}$ Duadji, dan Tresiana, Kota Layak Anakyang Berkelanjutan.

${ }^{8}$ QS. al-Maidah: 2. 
perkembangan Islam sejak awal telah dicontohkan dalam kisah Nabi ketika terjadi Perang Ahzab, dengan semangat kerjasama dan tolong-menolong yang tinggi, umat Islam berhasil menggali parit sepanjang 5000 hasta. Untuk melaksanakan tugas ini, Nabi membagi para sahabat menjadi beberapa grup. Setiap grup terdiri dari sepuluh orang dan setiap grup diarahkan untuk mengali parit sepanjang 40 hasta dan Nabi juga turut terlibat dalam proyek tersebut, Ketika musuh datang, Allah mengaruniakan bantuannya kepada umat Islam.

Esensi pokok tulisan ini adalah, mendudukan pemahaman yang benar dalam merumuskan konsepsi pembangunan kota layak anak yang berbasis kolaborasi (collaborative governance), sehingga diharapkan akan lahir berbagai kebijakan dan program anak pada tingkat kabupaten/kota yang berkarakter holistik, integratif, dan berkelanjutan. Friedman memandang esensi pokok pembangunan kolaboratif adalah sebuah bentuk aplikasi atas pengetahuan ke dalam tindakan dan mengelompokkan perencanaan sebagai social reform, policy analysis, social learning, dan social mobilization. ${ }^{9}$ Perubahan pendekatan ini menjadikan perencanaan pembangunan tidak hanya milik pemerintah, tetapi milik kelompok-kelompok masyarakat. Selanjutnya Ansell dan Gash (2007) memperkuat bahwa konsep membangun, termasuk merumuskan kebijakan pembangunan kota layak anak melalui proses kolaboratif, adalah suatu proses adaptive system, dimana pendapat-pendapat yang berbeda dari berbagai pihak yang akhirnya menghasilkan suatu konsensus. ${ }^{10}$ Proses kolaboratif menurut model ini akan terdiri dari berbagai tahapan, yaitu dimulai dari adanya dialog secara tatap muka (face-to-face dialogue), membangun kepercayaan (trust building), membangun komitmen terhadap proses (commitment to the process), berbagi pemahaman (shared understanding), dan kemudian terbentuknya hasil sementara (intermediate outcome). Tahapan ini merupakan suatu siklus sehingga terjadi proses pembelajaran di dalamnya.

Tulisan ini bertujuan menjelaskan 2 (dua) hal, yakni: 1) pemetaan permasalahan utama anak dalam pembangunan dan potensi-potensi yang ada di daerah dari aspek kebijakan, kelembagaan/organisasi anak yang bisa di-

\footnotetext{
9John Friedmann, "Planning in the Public Domain: From. Knowledge to Action" (New Jersey: Princeton University Press,1987).

${ }^{10}$ Ansell dan Gash, "Collaborative Governance in Theory and Practice."
} 
kembangkan; 2) mengembangkan model collaborative governance dalam pembangunan kota/kabupaten layak anak di Provinsi Lampung.

Metode penelitian yang digunakan adalah kualitatif deskriptif. Data yang digunakan adalah data primer dan sekunder. Data sekunder diperoleh dari pemerintah daerah berupa dokumentasi yang relevan. Data primer didapat dari wawancara dan observasi. Teknik pengumpulan dilakukan dengan: 1) observasi; 2) wawancara mendalam; 3) dokumen; dan 4) Focus Group Discussion (FGD). Data yang dikumpulkan, dianalisis dengan analisis kualitatif, dengan model interaktif dari Miles dan Huberman. ${ }^{11}$ Data primer berupa kata-kata, tuturan dan tindakan atau perilaku informan, serta data sekunder diperoleh dari berbagai dokumen, arsip, jurnal, karya ilmiah, data statistik dan lain-lain. Lokasi penelitian dilaksanakan di Kota Bandar Lampung, yang memiliki 15 kabupaten/kota, dengan subjek sasaran beberapa lembaga pemerintah dan non pemerintah.

\section{B. Anak dan Isu Kesehatan}

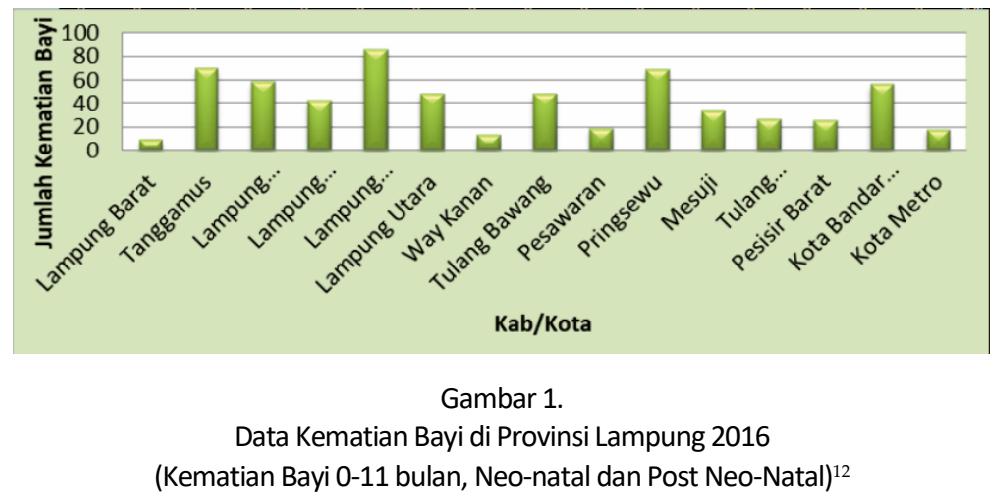

Data kematian bayi di Provinsi Lampung di tahun 2016, sebanyak 627 kasus. Kabupaten tertinggi dalam hal ini adalah Lampung Tengah (86 kasus), sedangkan kabupaten terendah adalah Lampung Barat sebanyak 9 kasus.

\footnotetext{
${ }^{11}$ B. Mathew MIles and A. Michael Huberman, Analisis Data Kualitatif: Buku Sumber tentang Metode-metode Baru (Jakarta: UI Press, 1992).

${ }^{12}$ Sumber: Profil Gender dan Anak LPPM Unila. 2017.
} 
Kabupaten-kabupaten lain yang mempunyai jumlah kasus relatif tinggi antara lain: Tanggamus (70 kasus), Pringsewu (69 kasus), Lampung Selatan (59 kasus), dan Kota Bandar Lampung (57 kasus). Sementara itu kabupatenkabupaten yang relatif kecil jumlah kasusnya antara lain Tulang Bawang Barat (27 kasus), Pesawaran (19 kasus), Kota Metro (18) dan Way Kanan (13 kasus).

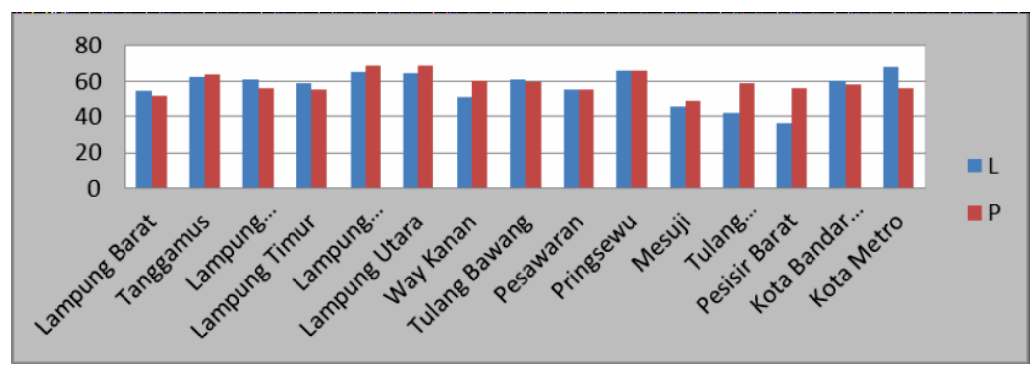

Gambar 2.

Persentase Balita yang Mendapat Imunisasi Lengkap menurut Jenis Kelamin di Kabupaten/Kota di Provinsi Lampung 2016

Secara keseluruhan balita yang mendapatkan imunisasi lengkap di Provinsi Lampung pada tahun 2016 mencapai 60,4\%. Terdapat perbedaan (disparitas) antara balita laki-laki dan perempuan yang mendapatkan imunisasi lengkap. Balita perempuan mencapai $61,5 \%$ sedangkan balita laki-laki hanya sebesar 59,2\%. Dengan kata lain disparitasnya mencapai 2,3\%. Namun demikian pola ini tidak merata untuk seluruh kabupaten yang ada di Provinsi Lampung. Kabupaten Pesisir Barat merupakan kabupaten yang tertinggi indeks disparitasnya yakni mencapai 19,84\% yang diikuti kabupaten Tulang Bawang Barat dengan 17,46\% dan Way Kanan (9,15\%). Sementara itu kabupatenkabupaten yang persentase imunisasi balita laki-laki lebih tinggi dibandingkan balita perempuan adalah kabupaten: Lampung Barat (2,68\%), Lampung Selatan (4,43\%), Lampung Timur (3,99\%), Pesawaran (1,25\%), Pringsewu $(0,01)$ dan Kota Bandar Lampung $(2,38)$.

\section{Anak dan Isu Anak Berhadapan dengan Hukum (ABH)}

${ }^{13}$ Sumber: Profil Gender dan Anak LPPM Unila, 2017. 
Jumlah keseluruhan anak yang berhadapan hukum (ABH) di Provinsi Lampung pada tahun 2016 mencapai 230 anak yang terdapat dan tersebar di 11 kabupaten/kota. Kota Bandar Lampung dan Kabupaten Lampung Utara memiliki jumlah $\mathrm{ABH}$ yang relatif tinggi dibandingkan daerah lain. Jumlah $\mathrm{ABH}$ di Bandar Lampung mencapai 78 orang $(33,9 \%)$ dari jumlah keseluruhan.

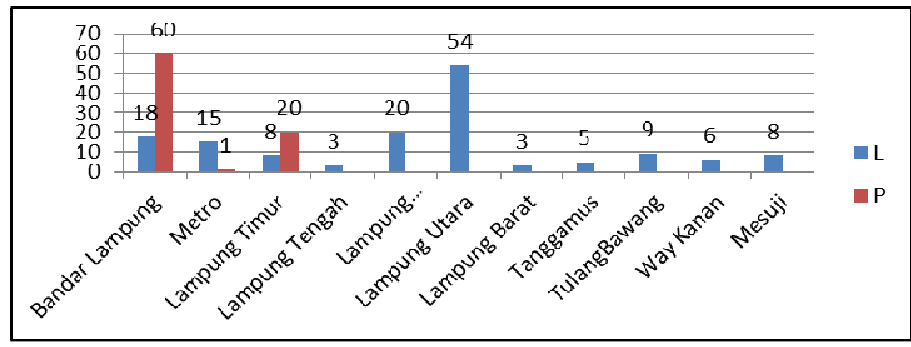

Gambar 3.

Anak Berhadapan dengan Hukum ${ }^{14}$

Sementara jumlah ABH di Lampung utara mencapai 54 anak (23,5\%). Jumlah $\mathrm{ABH}$ perempuan di Bandar Lampung bahkan lebih tinggi dibandingkan laki-laki. Jumlah $\mathrm{ABH}$ perempuan di Bandar Lampung mencapai 60 orang sedangkan $\mathrm{ABH}$ laki-laki berjumlah 18 orang. Jumlah $\mathrm{ABH}$ perempuan di Kabupaten Lampung Timur juga lebih tinggi (20 orang) dibandingkan ABH lakilaki (8 orang). Fenomena seperti ini agak berbeda dengan pola umum dimana $\mathrm{ABH}$ laki-laki lebih banyak bahkan mondominasi dibandingkan $\mathrm{ABH}$ perempuan.

\section{Anak dan Isu Kekerasan}

Pada Gambar 4, tingginya angka kekerasan di Provinsi Lampung dilihat dari pekerjaan, maka tertinggi dialami oleh pelajar (laki-laki 57,4\% dan perempuan 45,4\%), Keterkaitan pendidikan dengan tingginya korban kekerasan dilihat dari aspek faktor resiko personal/individual. Pelajar (SD,SMP dan SMA) beresiko menjadi korban kekerasan. Pendidikan SLTP merupakan level pendidikan yang belum memiliki kemandirian, usia muda, belum memiliki sikap terhadap ketidaksetaraan peran gender dan kekerasan. Ini yang menjadi pemicu tingginya korban kekerasan pada level pendidikan SLTP. Selanjutnya,

${ }^{14}$ Sumber: Profil Gender dan Anak LPPM Unila, 2017. 
korban kekerasan pada level perguruan tinggi juga tinggi untuk Provinsi Lampung. Ada banyak kemungkinan menjadi penyebabnya, diantaranya norma gender yang mendukung ketidakadilan gender, penerimaan ideologi tentang laki-laki berhak mendapatkan layanan seksual dan subordinasi perempuan dan norma sosial yang mendukung kekerasan, Lemahnya sanksi terhadap kekerasan terhadap perempuan di perguruan tinggi, dan Lemahnya lembaga negara/kampus. Diperlukan penguatan norma-norma gender di perguruan tinggi yang mendukung keadilan gender, salah satunya melalui penguatan kurikulum yang berkeadilan dan berkesetaraan gender.

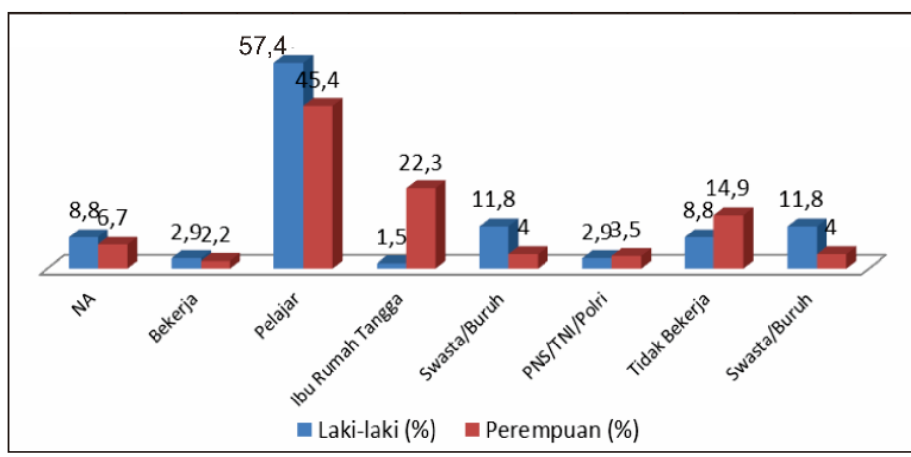

Gambar 4.

Korban Kasus Kekerasan di Lampung menurut Pekerjaan ${ }^{15}$

\section{E. Anak dan Isu-isu Bidang Sosial}

Jumlah keseluruhan anak balita terlantar di Provinsi Lampung pada tahun 2016 mencapai 4.821 orang. Jumlah terbesar berada di Kabupaten Lampung Tengah yakni sebanyak 931 orang (21,7\%). Jumlah terkecil ada di Kota Metro yakni sebanyak 34 orang $(0,7 \%)$. Persoalan balita terlantar ini merefleksikan rendahnya tanggung jawab elemen masyarakat (pemerintah, orangtua dan masyarakat) terhadap persoalan sosial yang ada di sekitarnya.

Jumlah keseluruhan anak penyandang disabilitas di Provinsi Lampung Tahun 2015 mencapai 4.335 orang. Data ini belum terpilah gender sehingga tidak dapat diketahui tingkat kesenjangan gendernya. Kabupaten Lampung

${ }^{15}$ Profil Gender dan Anak LPPM Unila, 2017 
Tengah mempunyai jumlah anak disabilitas terbanyak yakni 829 orang dan Kabupaten Tulang Bawang Barat merupakan kabupaten dengan jumlah penyandang disabilitas terkecil yakni 4 orang.

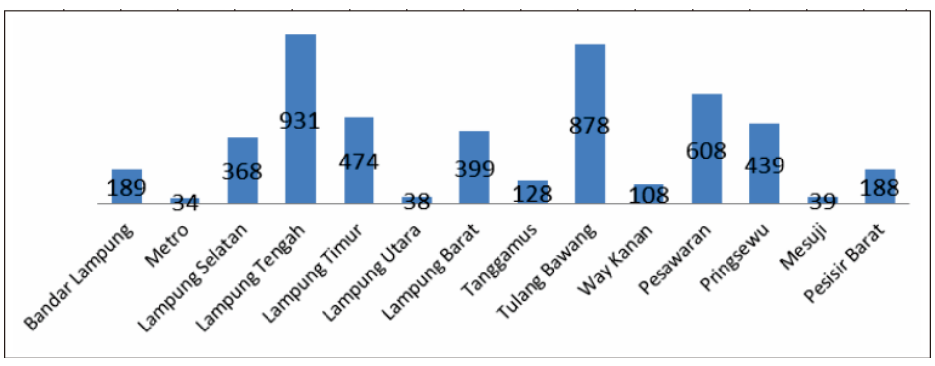

Gambar 5.

Distribusi Balita Terlantar di Provinsi Lampung Berdasarkan Kabupaten/Kota Tahun $2015^{16}$

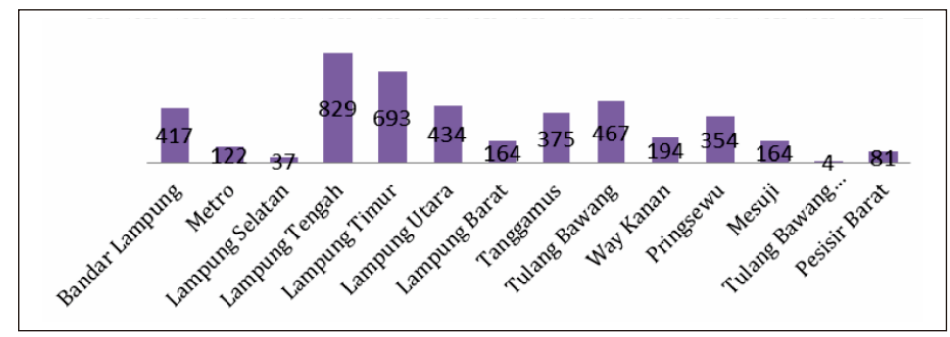

Gambar 6.

Distribusi Anak dengan Disabilitas di Provinsi Lampung Tahun 2015 Berdasarkan Kabupaten/Kota Tahun ${ }^{17}$

Mengacu pada data-data di atas, di Provinsi Lampung masih menunjukkan beberapa indikasi, bahwa hak anak belum terpenuhi secara optimal. Masalahmasalah yang muncul antara lain: 1) tingginya angka kekerasan terhadap anak; 2) tasih banyaknya anak yang menghadapi persoalan-persoalan hukum yang seringkali kurang terpenuhinya hak-hak mereka; 3) masih rendahnya layanan kesehatan; 4) masih dijumpai adanya gizi kurang dan buruk, serta masalah sosial anak dan lain-lain masih seringkali dijumpai. Pemerintah daerah sendiri

${ }^{16}$ Profil Gender dan Anak LPPM Unila, 2017.

${ }^{17}$ Profil Gender dan Anak LPPM Unila, 2017. 
telah berupaya untuk meningkatkan kualitas anak, dengan menerapkan Pengarusutamaan Hak Anak (yang selanjutnya disebut PUHA), yaitu suatu strategi mengintegrasikan isu-isu dan hak-hak anak ke dalam setiap tahapan pembangunan mulai dari perencanaan, pelaksanaan, pemantauan dan evaluasi atas peraturan perundang-undangan, kebijakan, program dan kegiatan dan anggarannya dengan menerapkan prinsip kepentingan terbaik bagi anak. Strategi ini merupakan manifestasi dari perubahan paradigma pembangunan Anak dari semula parsial, segmentatif, dan sektoral menjadi holistik, integratif, dan berkelanjutan.

Pemetaan permasalahan anak di atas, menunjukkan adanya sebuah komposisi dan pola perilaku anak ini sangat berkaitan dengan perlakuan atau berbagai kebijakan dari pihak seperti, Pemerintah, orang tua, maupun lembaga tertentu, yang diberikan kepada anak. Berbasis data lapang, ada beberapa hal yang menjadi temuan penting, yaitu: 1) data pembangunan anak belum menunjukkan kemajuan yang berarti; 2) undang-undang tentang perlindungan anak, walau telah mendapatkan perhatian, realisasi program dan kegiatan harus segera diwujudkan; 3) pencapaian keberhasilan pembangunan perlindungan anak bidang pendidikan, yang banyak melibatkan stakeholders, bisa dipakai sebagai rujukan dan pintu masuk untuk peningkatan perlindungan anak yang lebih luas.

\section{F. Potensi Dukungan Pembangunan Anak}

IULA dan Unicef menggambarkan prasyarat pembangunan kota layak anak, diantaranya: 1) adanya kemauan dan komitmen pimpinan daerah yang dicerminkan dalam peraturan daerah; 2) tersedia sistem data dan data dasar yang digunakan untuk perencanaan, penyusunan program, pemantauan, dan evaluasi; 3) adanya sosialisasi hak anak yang menjamin penyadaran hak-hak anak pada anak dan orang dewasa; 4) adanya produk hukum yang ramah anak dengan tersusunnya peraturan perundangan mempromosikan dan melindungi hak-hak anak; 5) tersedianya wadah untuk mempromosikan kegiatan yang melibatkan anak dalam program-program yang akan mempengaruhi mereka; mendengar pendapat mereka dan mempertimbangkannya dalam proses pembuatan keputusan; 6) adanya program untuk memperkuat kemampuan keluarga dalam pengasuhan dan perawatan anak; 7) adanya kemitraan dan jaringan dalam pemenuhan hak dan perlindungan anak; 8) adanya kelembaga- 
an yang mengkoordinasikan semua upaya pemenuhan hak anak. ${ }^{18}$ Dari delapan prasyarat di atas, Provinsi Lampung memiliki potensi yang bisa dikembangkan, mulai dari komitmen beberapa pejabat daerah berupa kebijakan-kebijakan, wadah sosialisasi dan partisipasi, serta berbagai kelembagaan dan organisasi non pemerintah yang memiliki komitmen perjuangan perlindungan dan tumbuh kembang anak. Beberapa potensi yang bisa dikembangkan tampak dalam Tabel 1.

Tabel 1.

Potensi Kebijakan dan Kelembagaan Anak di Provinsi Lampung ${ }^{19}$

\begin{tabular}{|c|c|c|}
\hline No. & Kebijakan & Kelembagaan Anak \\
\hline 1 & $\begin{array}{l}\text { Perda Provinsi Lampung No. } 4 \text { Tahun } 2008 \\
\text { Tentang Pelayanan Terhadap Hak Anak }\end{array}$ & $\begin{array}{l}\text { Lembaga Perlindungan Anak (LPA) } \\
\text { Provinsi Lampung dan } \\
\text { Kabupaten/Kota }\end{array}$ \\
\hline 2 & $\begin{array}{l}\text { Perda Provinsi Lampung No. } 5 \text { Tahun } 2012 \\
\text { tentang Penyelenggaraan Pendidikan Berbasis } \\
\text { Agama dan Budaya }\end{array}$ & $\begin{array}{l}\text { Himpunan Aktivis Sosial Peduli Anak } \\
\text { dan Masyarakat Miskin Lampung } \\
\text { HASPAMII }\end{array}$ \\
\hline 3 & $\begin{array}{l}\text { Perda Provinsi Lampung No. } 10 \text { Tahun } 2013 \\
\text { tentang Pelayanan dan Pemenuhan Hak-Hak } \\
\text { Penyandang Disabilitas }\end{array}$ & $\begin{array}{l}\text { DPP Forum Komunikasi Anak Bangsa } \\
\text { "FKAB" Provinsi Lampung }\end{array}$ \\
\hline 4 & $\begin{array}{l}\text { Peraturan Gubernur Lampung Nomor } 35 \text { Tahun } \\
2013 \text { tentang Pengembangan Kabupaten/Kota } \\
\text { Layak Anak }\end{array}$ & $\begin{array}{l}\text { Forum Komunikasi Anak Lampung } \\
\text { (FOKAT) }\end{array}$ \\
\hline 5 & $\begin{array}{l}\text { Keputusan Gubernur Lampung No. G/733/II.11/ } \\
\text { HK/2013 tentang Pembentukan Kelompok } \\
\text { Kerja Anak Berhadapan Dengan Hukum } \\
\text { Provinsi Lampung Periode 2013-2016 }\end{array}$ & $\begin{array}{l}\text { Unit Pelayanan Perempuan dan } \\
\text { Anak (UPPA) Kepolisian Daerah } \\
\text { Lampung }\end{array}$ \\
\hline 6 & $\begin{array}{l}\text { Keputusan Gubernur Lampung No. G/720/ } \\
\text { II.11/HK/2013 tentang Forum Koordinasi Stan- } \\
\text { dar Pelayanan Minimal Terpadu Perempuan } \\
\text { dan Anak Korban Kekerasan di Provinsi } \\
\text { Lampung Tahun } 2013\end{array}$ & $\begin{array}{l}\text { Puslitbang Wanita, Anak Univ. } \\
\text { Lampung }\end{array}$ \\
\hline 7 & $\begin{array}{l}\text { Keputusan Gubernur Lampung Nomor } \\
\text { G/681/B.VII/HK/2011 Tentang Penetapan } \\
\text { Struktur Organisasi dan Susunan Pengurus } \\
\text { Telepon Sahabat Anak (TeSA) } 129 \text { Provinsi } \\
\text { Lampung Periode Tahun 2011-2014 }\end{array}$ & $\begin{array}{l}\text { Lembaga Advokasi Anak (LADA) } \\
\text { Provinsi Lampung }\end{array}$ \\
\hline 8 & Surat Edaran Gubernur Lampung Nomor & Telepon Sahabat Anak (TESA) 129 \\
\hline
\end{tabular}

${ }^{18}$ IULA \& UNICEF, "Partnership to Create Child Friendly City: Programming for Child Rights with Local Authorities" (Italy: UNICEF Innocenti Research Centre, 2002).

${ }^{19}$ Duadji, Noverman dkk, "Model Percepatan Kota Layak Anak." 
870/2539/II.11/2013 Tentang Pelayanan Terpadu Terhadap Perempuan dan Anak Korban Tindak Kekerasan di Provinsi Lampung

9 Surat Edaran Gubernur Lampung Nomor 870/2539/II.11/2013 Tentang Pelayanan Terpadu Terhadap Perempuan dan Anak Korban Tindak Kekerasan di Provinsi Lampung

Keputusan Gubernur Lampung Nomor G/815/B.VII/HK/2013 Tentang Pembentukan Kelompok Kerja Pengembangan Anak Usia Dini Holistik Integratif Provinsi Lampung Tahun 2013-2015

11 Perjanjian Kerjasama Antara Pemerintah Provinsi Lampung dengan Kabupaten/Kota seProvinsi Lampung Nomor G/719/B.VII/HK/2013 Tanggal 20 September 2013 Tentang Kerjasama Pengembangan Kabupaten/Kota Layak Anak.
Provinsi Lampung

Children Crisis Centre (CCC)

Pusat Pelayanan Terpadu

Pemberdayaan Perempuan dan

Anak Lamban Indoman Putri (LIP)

Lembaga Pemberdayaan Perempuan dan Anak (LPPA)

Berbasis data lapang dan analisis data, maka tulisan ini mendapati bahwa Provinsi Lampung memiliki potensi kelembagaan masyarakat yang memiliki kepedulian terhadap pembangunan anak. Berdasar tabel di atas, tercatat ada 11 organisasi dan kelembagaan anak. Sumanto dalam Tresiana dan Duadji berpendapat, adanya kelembagaan masyarakat dapat menjadi kekuatan yang cukup penting dalam pembangunan daerah. Kemunculan aktivitas organisasi dan kelembagaan anak memiliki potensi untuk terjalinnya jejaring, partnership pemerintah dalam menyelesaikan isu-isu pembangunan. Kelembagaan dan organisasi juga bisa menjadi media untuk menggerakkan kelompok masyarakat lainnya. Dengan demikian, pemetaan terhadap adanya berbagai dukungan kebijakan dan kelembagaan/organisasi anak mendapati kesimpulan bahwa kehadiran keduanya berkontribusi bagi perubahan relasi kekuasaan antara pemerintah dan aktor di luar pemerintah. Proses tersebut, membuktikan tidak ada kekuasaan yang memiliki kesempurnaan, sehingga selalu memerlukan interaksi sehari-hari dengan para pemberi mandate untuk mendengarkan suara mereka, dan menjadikan pendapat-pendapat mereka sebagai 
pertimbangan dalam pengambilan keputusan, atau bahkan keputusan itu dibuat bersama. ${ }^{20}$

\section{G. Kota Layak Anak Berbasis Collaborative Governance}

Kebijakan Kota/Kabupaten Layak Anak (KLA) merupakan upaya Pemerintahan Kota/Kabupaten untuk mempercepat implementasi Konvensi Hak Anak (KHA) dari kerangka hukum ke dalam definisi, strategi, dan intervensi pembangunan seperti kebijakan, institusi, dan program yang layak anak. Secara normatif yuridis pengembangan KLA terdapat dalam World Fit for Children, Keputusan Presiden Nomor 36 Tahun 1990 tentang Ratifikasi Konvensi Hak-hak Anak, Undang-Undang Dasar 1945 (Pasal 28b, 28c), Program Nasional bagi Anak Indonesia 2015, UU Nomor 23 Tahun 2002 tentang Perlindungan Anak, dan Permenneg Pemberdayaan Perempuan dan Anak Nomor 2 Tahun 2009 tentang Kebijakan KLA.

Kota Layak Anak sendiri menurut Unicef Innocenti Research Centre ${ }^{21}$ adalah adalah kota yang menjamin hak-hak setiap anak sebagai warga kota. Dalam konteks kebijakan publik, maka adopsi nilai-nilai anak dalam kebijakan publik seyogyanya memenuhi beberapa unsur, yakni: 1) dimensi anak memengaruhi keputusan terhadap kota/kabupaten; 2) dengapresiasi pendapat anak tentang kota, Misalnya kawasan bebas asap rokok; 3) tersedianya Ruang Terbuka Hijau (RTH) sebagai sarana bermain bagi anak yang aman dan nyaman bagi ruang bermain, berkreasi, tumbuh kembang bagi anak. Misalnya kebijakan tentang pemenuhan gizi bagi balita melalui posyandu atau dasawisma.; 4) pelayanan dasar seperti kesehatan dan pendidikan, misalnya melalui penidikan dasar gratis bagi anak dan jaminan kesehatan, ketersediaan Puskesmas yang mudah dijangkau; 5) mendapatkan air minum segar dan mempunyai akses terhadap sanitasi yang baik. 6) melindungi anak dari eksploitasi, kekejaman, dan perlakuan salah; 7) aman berjalan di jalan melalui ketersediaan

\footnotetext{
${ }^{20}$ Novita Tresiana dan Noverman Duadji, "Multi Stakeholders Governance Body Model in Achieving The Excellence Public Policy”, Jurnal Mimbar 32, no. 2 (2016): 401-411.

${ }^{21}$ IULA \& UNICEF, "Partnership to Create Child Friendly City."
} 
jalan yang baik, memadai, mudah bertemu dan bermain dengan temannya; 8) mempunyai ruang hijau untuk tanaman dan hewan; hidup di lingkungan yang bebas polusi; 9) anak dapat dilibatkan dalam banyak hal, termasuk dalam kegiatan budaya, temu anak dan berbagi pengalaman dalam kehidupan sesuai dengan keampuan anak; 10) setiap anak berhak atas kehidupan untuk pegembangan fisik, mental, spritual, dan moral.

Untuk ketercapaian hak anak di atas, maka berdasarkan hasil penelitian yang dilakukan Duadji, Tresiana dan Putri, ${ }^{22}$ dirumuskan model collaborative governance untuk merumuskan kebijakan pembangunan anak, yang selama ini dilakukan parsial, terpisah, belum berintegrasi dengan kelompok/kelembagaan masyarakat lainnya, kurang mengikutsertakan atau melibatkan potensi dan jejaring kelembagaan yang ada di masyarakat. Penguatan kebijakan pembangunan kota/kabupaten layak anak akan berhasil, manakala semua komponen kelembagaan masyarakat melakukan komunikasi, tindakan dan kerjasama untuk mengambil suatu keputusan publik yang meupakan hasil konsensus melalui suatu proses dialog secara tatap muka. ${ }^{23}$

Dalam kebijakan membangun kota/kabupaten layak anak, pada intinya pemerintah dapat melakukan suatu jejaring/kemitraan yang seluas-luasnya dengan melibatkan semua pihak yang ada di kota. Kemitraan dapat dibangun dengan melibatkan sektor swasta, tokoh masyarakat, tokoh adat, pemerintah kota dari masing-masing departemen atau sektor, lembaga non pemerintah, dan masyarakat sipil. Kemitraan yang terbangun dapat saling berintegrasi dan bersinergi menjadi suatu kesatuan yang saling mengisi dan membutuhkan satu dengan lainnya.

Ketiadaan dukungan jejaring kemitraan kelembagaan terhadap perasalahan anak berkontribusi terhadap kegagalan dalam memberikan perlindungan dan tumbuh kembang anak. Oleh karena itu perencanaan dan perumusan kebijakan mutlak dilakukan segenap komponen masyarakat. Untuk itu model Collaborative Governance perlu dilakukan sebagaimana tertera dalam Gambar 7.

\footnotetext{
${ }^{22}$ Duadji, Noverman dkk, "Model Percepatan Kota Layak Anak."

${ }^{23}$ Ansell dan Gash, "Collaborative Governance in Theory and Practice."
} 
Penetapan model Collaborative Governance didasari temuan lapangan yaitu: 1) masih banyak persoalan-persoalan anak yang harus di respons dalam pembangunan, diantaranya persoalan anak di bidang kesehatan, kekerasan, disabilitas, hukum dan sosial hukum; 2) adanya potensi dukungan pembangunan kebijakan kota/kabupaten layak anak, mulai dari adanya berbagai dukungan kebijakan anak serta kehadiran lembaga penyedia layanan anak berupa lembaga masyarakat dan organisasi masyarakat di Provinsi Lampung.

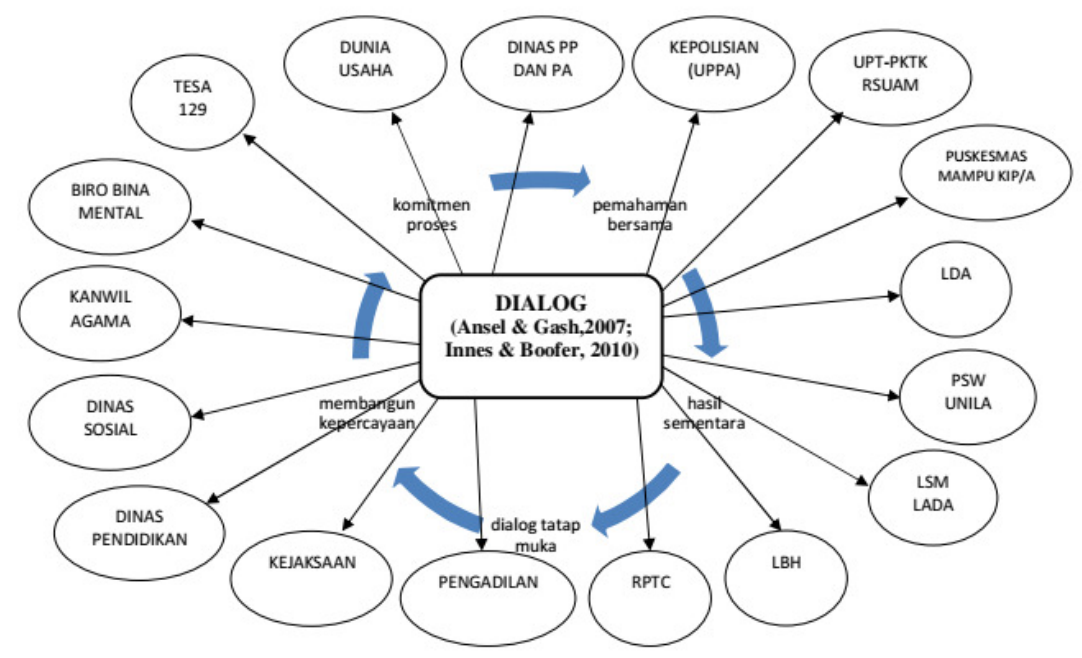

Gambar 7.

Model Collaborative Governance dalam Membangun KLA

Berdasarkan olah data wawancara dan observasi, maka ditemukan aspekspek penting penting sebagai penentu keberhasilan pembangunan kebijakan kota/kabupaten layak anak diantaranya:

Pertama, dibutuhkan prasyarat adanya jejaring kerja (networking) dari kelembagaan masyarakat dan organisasi kemasyarakatan. Jejaring kerja (networking), berkenaan dengan hubungan formal/informal dalam rangka pelibatan/pemanfaatan raw material policy, membangun proses pembelajaran bersama, sehingga melalui networking diharapkan berkontribusi bagi masuknya isu-isu anak dalam program pembangunan. Pembangunan kebijakan kota/kabupaten layak anak dalam konteks jejaring kerja (networking), me- 
mandang pentingnya kebijakan/program seharusnya muncul dari kesalinghubungan (interplay) antara orang dan organisasi. Dengan menggunakan bahasa teknologi komputer, Parsons melihat jejaring kerja (networking) sebagai menjalin kontak untuk mendapat keuntungan dan saling terhubung. ${ }^{24}$ Oleh karenanya kebijakan atau program akan terbentuk dalam konteks relasi dan dependensi. ejaring kerja (networking) lebih ditekankan pada tindakan kerjasama (mitra) yang dilakukan perumus kebijakan, khususnya lintas kelembagaan/organisasi. Jejaring antara pemerintah dan lembaga-lembaga lain merupakan kebutuhan dalam pengelolaan organisasi pemerintah (good governance) yang juga akan memberikan banyak penghematan dan akan dicapai hasil serta manfaat yang berlipat ganda jika para pihak dalam organisasi memiliki kesamaan orientasi membentuk jaringan. Sulistiyani mengemukakan bahwa, jejaring sebagai suatu bentuk persekutuan antara dua pihak atau lebih, yang dalam hal ini adalah pemerintah dengan stakeholders, dan kemudian membentuk suatu ikatan kerjasama atas dasar kesepakatan dan rasa saling membutuhkan dalam rangka meningkatkan kapasitas dan kapabilitas disuatu bidang usaha tertentu, atau tujuan tertentu, sehingga dapat memperoleh hasil yang lebih baik.25 Selanjutnya, dikemukakan oleh Sulistiyani bahwa hal diatas dapat terbentuk apabila dipenuhinya syarat-syarat sebagai berikut: 1) ada dua pihak atau lebih; 2) yang berhubungan memiliki kesamaan visi dalam mencapai tujuan; 3) ada kesepakatan diantara yang berinteraksi; 4) saling membutuhkan. Dengan demikian, tujuan terjadinya suatu jejaring kerja adalah untuk mencapai hasil yang lebih baik, dengan saling memberikan manfaat antara pihak yang saling berinteraksi. Jaringan kerja idealnya memberikan keuntungan, baik kepada pemerintah maupun stakeholders, bukan sebaliknya ada satu pihak yang dirugikan.

Riedge dan Lindsay memperkuat bahwa sangat pentingnya pengembangan kebijakan/program publik, termasuk kebijakan pembangunan kota/

\footnotetext{
${ }^{24}$ Wayne Parsons, Public Policy: Pengantar Teori dan Praktik Analisis Kebijakan" (Jakarta: Kencana, 2006).

${ }^{25}$ Ambar Teguh Sulistiyani "Kemitraan dan Model-model Pemberdayaan" (Yogyakarta: Gama Media, 2004).
} 
kabupaten layak anak melalui knowledge based partnership with stakeholders. ${ }^{26}$ Mengacu pada pendapat Mc. Adam dan Reid yang menyatakan adanya empat hal pokok yang saling berinteraksi dalam pengetahuan manajemen (knowledge management), yaitu: konstruksi pengetahuan (knowledge construction), mewujudkan pengetahuan (knowledge embodied), diseminasi pengetahuan (dissemination knowledge) serta aplikasi pengetahuan (the application of knowledge),,27 maka tujuan pokok dari jejaring kerja/kemitraan antar pemerintah dengan stakeholders adalah untuk memfasilitasi transfer pengetahuan dan sosial berbasis ilmu pengetahuan yang efektif antar stakeholders dengan pemerintah. Pandangan demikian sangatlah masuk akal mengingat stakeholders memiliki perbedaan pandangan dan perbedaan kapasitas, karena itu pengembangan kemitraan antar pemerintah dan stakeholders diharapkan mampu membangun aliansi strategis yang berfokus pada upaya mewujudkan hak-hak anak, yakni perlindungan dan tumbuh kembang anak.

Kedua, kolaboratif dalam merumuskan kebijakan pembangunan kota/ kabupaten layak anak dilakukan melalui proses dialog tatap muka. Pada dasarnya model kolaboratif memiliki karakter utama kerjasama. Proses kerjasama tersebut akan berlangsung dengan baik jika terjadi dialog, sebagaimana ditegaskan oleh Innes dan Booher ${ }^{28}$ sebagai authentic dialogue. Dalam hal ini, setiap pelaku yang duduk bersama saling menghargai, empati, terjadi hubungan timbal balik dan saling menguntungkan. Dengan demikian, dialog hanya akan terjadi jika para stakeholders berpartisipasi dan duduk bersama dalam memecahkan permasalahan anak.

Pembangunan kota/kabupaten layak anak dari perspektif model collaborative governance, menurut Anshel dan Gash ${ }^{29}$ dan Innes \& Booher ${ }^{30}$ memiliki proses dimulai dari mengidentifikasi permasalahan, mengidentifikasi pe-

\footnotetext{
${ }^{26}$ Andreas Riege dan N. Linsey, "Knowledge Management in The Public Sector: Stakeholders Partnership in The Public Policy Development”, Journal of Knowledge Management 10 , no. 3 (2006): 21-42.

${ }^{27}$ Mc Adam, R dan Reid, R, “A Comparison of Public and Privat Sector Perceptions and Use of Knowledge Management", Journal Eurepoean Industrial Training 24,, no. 6 (2000): 25-43.

${ }^{28}$ J. E. Innes, dan D. E. Booher, "Beyond Collaboration Democratic Governance for a Resilient Society dalam Planning with Complexity Complexity, An Introduction to Collaborative Rationality or Public Policy (Routledge: Oxon, 2010).

${ }^{29}$ Ansell dan Gash, "Collaborative Governance in Theory and Practice."

${ }^{30}$ Innes, dan Booher, "Beyond Collaboration Democratic Governance."
} 
mangku kepentingan, membangun kepercayaan, membangun pemahaman bersama, menghasilkan upaya pemecahan masalah bersama dan membangun komitmen bersama. Hal ini sesuai dengan definisi dari proses kolaboratif, yaitu suatu proses yang membawa para pemangku kepentingan publik ke dalam suatu forum bersama lembaga publik, untuk terlibat dalam pembuatan keputusan berorientasi konsensus. ${ }^{31}$ Proses kolaboratif merupakan upaya membangun komunikasi dengan multi-stakheholders. Multi-stakheholders adalah bagian dari suatu komunitas sosial dalam permasalahan tersebut yang memerlukan pengakuan terhadap keberadaannya. Hasil akhir dari proses dialog tatap muka, maka akan tergambar sejumlah informasi penting sebagaimana dikemukakan oleh Denhardt dan Denhardt ${ }^{32}$ bahwa sebuah keharusan melihat posisi penting kelembagaan dan organisasi masyarakat sebagai pemilik pemerintahan dan mampu bertindak bersama dalam memperjuangkan kebaikan yang lebih besar; mengusahakan nilai bersama dan kepentingan umum melalui dialog yang tersebar luas dan keterlibatan seluruh masyarakat. Dialog tatap muka menjadi media dan proses dimana para stakeholders, masyarakat bicara berdasarkan tematisasi isu-isu yang bersumber pada pengetahuan dan kapasitas mereka. Di sisi lain, perhatian dan responsiveness pemerintah daerah adalah menjadi ruang untuk mendengarkan, sehingga proses tersebut, membuktikan tidak ada kekuasaan yang memiliki kesempurnaan, selalu memerlukan interaksi sehari-hari dengan para warga, untuk mendengarkan suara mereka, dan menjadikan pendapat-pendapat mereka sebagai pertimbangan dalam pengambilan keputusan, atau bahkan keputusan itu dibuat bersama. Terjadinya dialog tatap muka membuktikan tidak ada kekuasaan yang memiliki kesempurnaan, sehingga selalu memerlukan interaksi sehari-hari dengan para pemberi mandat untuk mendengarkan suara mereka, dan menjadikan pendapat mereka sebagai pertimbangan dalam pengambilan keputusan, atau bahkan keputusan itu dibuat bersama.

Dialog tatap muka menurut Umriana, dkk. $^{33}$ dapat memunculkan kesadaran warga yang terlibat pada isu/objek tematik yang dibahas. Sedangkan

\footnotetext{
${ }^{31}$ Ansell dan Gash, "Collaborative Governance in Theory and Practice."

${ }^{32}$ Janet V. Denhardt dan Robert B. Denhardt, "The New Public Service: Serving, Not Steering (New York: M.E. Sharpe, 2007).

${ }^{33}$ Umriana, Moh. Fauzi, dan Hasyim Hasanah, "Hak Asasi Perempuan dan Kesetaraan Gender."
} 
menurut Duadji, Tresiana dan Putri dialog tatap muka pada akhirnya menjadi forum konsultasi dan penyaluran aspirasi untuk urusan pembangunan dan pelayanan anak di tingkat lokal. Hasil telaah di Provinsi Lampung menggambarkan bahwa dialog tatap muka dapat digunakan untuk merumuskan masalah dan mencari solusi permasalahan yang dihadapi oleh masyarakat, dan harapan tingginya dapat memberikan rekomendasi untuk melakukan tindakan tertentu, sekaligus sebagai media resolusi konflik di tingkat lokal. ${ }^{34}$

\section{H. Kesimpulan}

Pemetaan terhadap berbagai isu dan permasalahan anak yang terjadi di Provinsi Lampung meliputi berbagai bidang pembangunan, mulai dari bidang bidang kesehatan, bidang hukum, bidang sosial dan kekerasan. Untuk menyelesaikan persoalan anak, perlu dilakukan penguatan model kebijakan pembangunan Kota Layak Anak (KLA). Potensi-potensi kelembagaan yang dimiliki merupakan modal sosial untuk untuk menyelesaikan permasalahan anak. Untuk penguatan pembangunan Kota Layak Anak, maka perlu dikembangkan model collaborative governance, berbasis dialog tatap muka. Model tersebut selanjutnya berkontribusi dalam menyusun perencanaan/kebijakan pembangunan Kota Layak Anak.

Disarankan agar model collaborative governance yang dihasilkan, dapat ditindaklanjuti oleh Pemerintah Daerah Provinsi Lampung, dalam bentuk penguatan ruang dialog, membentuk sebuah forum dialog yang melibatkan semua kelembagaan dan organisasi anak di Provinsi Lampung secara kolaboratif, memperkuat kebijakan, sosialisasi pentingnya persoalan anak menjadi bagian penting dalam pembangunan.[s]

\section{Daftar Pustaka}

Ansell, C. dan A. Gash. "Collaborative Governance in Theory and Practice", Journal of Public Administration Research and Theory18(2007): 543-571.

Denhardt, Janet V. dan Robert B. Denhardt. The New Public Service: Serving, Not Steerin. New York: M.E. Sharpe, 2007.

\footnotetext{
${ }^{34}$ Duadji, Noverman dkk, “Model Percepatan Kota Layak Anak." 54.
} 
Duadji, Noverman dan Tresiana, Novita. Kota Layak Anak yang Berkelanjutan. Lampung: Aura Press, 2017.

Duadji, Noverman dkk. "Model Percepatan Kota Layak Anak". Laporan Penelitian, tidak dipublikasikan, Universitas Lampung, 2017.

Friedmann, John. Planning in the Public Domain: From Knowledge to Action. New Jersey: Princeton University Press, 1987.

Innes, J. E. dan D. E. Booher. "Beyond Collaboration Democratic Governance for a Resilient Society." dalam Planning with Complexity Complexity, An Introduction to Collaborative Rationality or Public Policy. Oxon: Routledge, 2010.

IULA \& UNICEF. Partnership to Create Child Friendly City: Programming for Child Rights with Local Authorities. Italy: UNICEF Innocenti Research Centre, 2002.

Mc Adam, R. dan R. Reid. "A Comparison of Public and Privat Sector Perceptions and Use of Knowledge Management." Journal Eurepoean Industrial Training 24, no. 6 (2000): 25-43.

Miles, M. dan A. M. Huberman. Analisis Data Kualitatif. Jakarta: UI Press, 2002.

Parsons, Wayne. Public Policy: Pengantar Teori dan Praktik Analisis Kebijakan. Jakarta: Kencana, 2006.

Riege, Andreas dan N. Linsey. "Knowledge Management in the Public Sector: Stakeholders Partnership in the Public Policy Development." Journal of Knowledge Management 10, no. 3 (2006): 21-42.

Sulistiyani, Ambar Teguh, Kemitraan dan Model-model Pemberdayaan. Yogyakarta: Gava Media, 2004.

Tresiana, Novita dan Noverman Duadji. "Multi-stakeholders Governance Body Model in Achieving The Excellence Public Policy", Jurnal Mimbar 32, no. 2 (2016): 401-411.

Tresiana, Novita dan Duadji, Noverman, "Kegagalan Pemaknaan Lembaga Musyawarah Perencanaan dan Pembangunan Desa dalam Mewujudkan Deepening Democracy", Jurnal Masyarakat, Kebudayaan dan Politik 29, no. 4 (2016): 191-203.

Tresiana, Novita dkk. "Profil Gender dan Anak Provinsi Lampung Tahun 2017”. Laporan Penelitian (tidak dipublikasikan), Kerjasama Dinas Pember- 
Noverman Duadji, Novita Tresiana

dayaan Perempuan dan Perlindungan Anak Provinsi Lampung dan Puslitbang Wanita, Anak dan Pembangunan LPPM Universitas Lampung. 2017.

Umriana, Anila, Moh. Fauzi, dan Hasyim Hasanah, "Hak Asasi Perempuan dan Kesetaraan Gender Melalui Dialog Warga." Sawwa: Jurnal Studi Gender 12, no. 1 (2016): 41-59.

Zaki, Muhammad. "Perlindungan Anak dalam Perspektif Islam", Jurnal Asas 6, no. 2 (2014): 1-15. 